Egyptian Journal of Aquatic Biology \& Fisheries

Zoology Department, Faculty of Science,

Ain Shams University, Cairo, Egypt.

ISSN $1110-6131$

Vol. 23(3): 423 - 439 (2019)

www.ejabf.journals.ekb.eg

\title{
Physico-chemical and bacteriological analysis of water quality in different types of water from the Ain Zada Dam of Bordj Bou Arreridj (Algeria).
}

\author{
Omar Elahcene $^{1,2}$; Hoda Abd El-Azim ${ }^{3 *}$ and Aziouz Aidoud ${ }^{4}$ \\ 1- Faculty of natural science and life, University Ziane Achour of Djelfa, Algeria \\ 2- Laboratory of Exploration and Valorization of Steppic Ecosystems, University of Ziane \\ Achour, Algeria \\ 3- National Institute of Oceanography and Fisheries, P.O. Box 182, Suez, Egypt \\ 4- University M'Hamed Bougara of Boumerdes, Algeria \\ * Corresponding author: Abdelazimh1968@yahoo.com
}

\begin{abstract}
ARTICLE INFO
Article History:

Online: Sept. 2019

Keywords:

Water quality

Bacteriology

Ain Zada Dam

Bordj Bou Arreridj
\end{abstract}

Received: April 22, 2019

Accepted: Aug. 28, 2019

\begin{abstract}
Physico-chemical and microbiological characteristics of the water samples were analysed following the standard methods to evaluate the quality of drinking water from (Raw water, Water before treatment, Water after treatment, Tap water) at the Ain Zada Dam to Bordj Bou Arreridj (Algeria) were analyzed. The results revealed that the physico-chemical and hydrochemical characteristics: (Temperature, PH, Conductivity, TDS, Turbidity, Dissolved Oxygen, Dry Residue, Ammonium, Total Hardness, Calcium and Magnesium, Chloride, Bicarbonate, Alkalinity, TAC, Iron, Manganese and Aluminum were found within permissible limits for drinking water as prescribed by WHO especially tap and after treatment water. Pearson correlation analysis, conducted to evaluate the relationship of water quality parameters, revealed a significant positive relationship between Total hardness with each of DO, Nitrate, Chlorides, and temperature $(0.979,0.961,0.941$ and 0.973$)$ and negative significance with most of other parameters. Calcium and Sodium were correlated positively with Sulfate (0.986, 0.602 respectively). The detection of Total coliform, total germ, E. coli, Fecal Streptococci and Clostridium Sulf-Red species was intended for human consumption suggests that Raw water and Water before treatment pose severe health risks to consumers and was found unsuitable for direct human consumption without treatment. The present study recommends mobilization of treatment interventions to protect the households from further possible consequences of using the water.
\end{abstract}

\section{INTRODUCTION}

Water quality is the summation of all physical, chemical, biological and aesthetic characteristics of water that influence its beneficial use (Boyde and Craig, 2009). Water is vital and most essential commodity to the survival of life, where water is the source of all biological lives and their sustenance (WHO, 2011). Water is often used for domestic purposes especially for drinking. These different purposes have its own requirements for the composition and purity and each body of water has to be analysed on a regular basis to confirm the suitability (Nidhi Saxena et al., 2011). Rapid urbanization and industrialization of society have resulted in high use of fertilizers for intensive agricultural production. 
Moreover, water bodies have been affected by excessive nutrient inputs as a result of enhanced human activity and extended wastewater generation. This is causing water eutrophication, which is a critical issue throughout the world (Bloem et al., 2017). Therefore, it is of major importance not only to have an adequate and accessible supply, but also to have quality water that is considered safe for human consumption (Amanatidou, et al., 2007). It is seriously affecting water quality, thus resulting in restriction of human drinking water supplies and deteriorating dissolved oxygen in water bodies, which is a danger for aquatic organisms (Carey and Migliaccio, 2009). Water for human consumption is supposed to be free from chemical substances and microorganisms which may cause disease in man. In addition, it should be pleasant to drink. That is, cool, clear, colorless and devoid of disagreeable taste or smell; water is said to be contaminated or polluted when it contains infective and parasitic agents, poisonous chemical substances, industrial wastes or sewage that make it unfit for its intended use (Arora, and Arora, 2008). Human activities in many parts of the world, e.g., animal production, still impact negatively on the environment and biodiversity. Some of the consequences of manmade pollution include transmission of diseases by water borne pathogens, eutrophication of natural water bodies, accumulation of toxic or recalcitrant chemicals in the soil, destabilization of ecological balance and negative effects on human health. So, its importance in our daily life makes it imperative that thorough microbiological and physio-chemical examinations be conducted on water (Lamikanra, 1999). Water quality is highly dependent on physical, chemical and microbiological conditions. The natural water analysis for physical, chemical and bacteriological properties including trace element contents are very important for public health studies. These studies are also a major part of pollution studies in the environment (Aminur Rahman, 2015). The water shortage in Algeria is on the way to become a crucial problem. Comparing to the needs of the population is increasing and is likely to rise in the future due to the impact of climate change and pollution as reported by many authors ( Reichwaldt and Ghadouani, 2012; Saoudi et al., 2017).

In Algeria, several reservoirs and dams are experiencing in recent years problems of degradation of water quality due mainly to the different sources of pollution (Boudoukha and Boulaarak, 2013; Guizani et al., 2016; Sakhel et al., 2017), due to population growth, the expansion of the industrial fabric and agricultural development. This often discharges from urban areas directly in streams without any treatment due to the lack of regulatory and remediation frameworks at the area (Bain et al., 2014). In the high plateaus region of Sétif, a large industrial, agricultural and urban activity develops throughout the entire Oued Boussellem watershed. The main river receives daily hundreds of cubic meters of waste that generate a total deterioration of the quality of surface waters in the region (Mebarkia et al., 2017). The dam of Ain Zada is locating on the high plains of Sétif at $815 \mathrm{~m}$ above sea level. The surface of the catchment area is approximately $2080 \mathrm{~km}^{2}$ (ANB BBA, 2013). It is supplied by three main valleys: Bousselem (with industrial discharge), Malah, and Ain Taghrout (with urban water discharge). The dam water is used for drinking water supplies, for irrigation, and as an extensive aquaculture of the royal carp (Cyprinus carpio). The water body of Ain Zada displayed different responses to abiotic factors (Saoudi et al., 2017). The water body of Ain Zada displayed different responses to abiotic factors. Ain Zada is considered an ancient dam, and is characterized by a large volume of 120 million $\mathrm{m}^{3}$, as well as low rainfall, which results in a slow renewal time. These conditions favor the development of the cyanobacteria as the only phytoplankton group in this dam (Saoudi et al., 2017). For the rest of the year, the 
region is subject to an irregular hydrological regime for the leaching of soluble chemicals, especially fertilizers and sewage from cities and urban centers with a mean annual flow of $0.42 \mathrm{~m}^{3} / \mathrm{s}$ measured at Farmatou station (Mebarkia, 2011). This enables the reservoir to receive a large share of annual liquid flow in few weeks and then it becomes finally stagnant water where evaporation is the dominant factor (Mebarkia et al., 2017). Therefore, adequate attention should be given to this source of water. It becomes imperative that the water meant for human consumption should be free of diseases causing germs and toxic chemicals that pose a threat to public health. Hence the objective of the present study is to determine selected physical and chemical parameters (Temperature, PH, Conductivity, TDS, Turbidity, Dissolved Oxygen, Dry Residue, Ammonium, Total Hardness, Calcium and Magnesium, Chloride, Alkalinity Bicarbonate, TAC, Iron, Manganese and Aluminum) as well as Bacteriological analyses in the different types of water from Ain Zada Dam to Bordj Bou Arreridj (common Ain Taghrout). The obtained results were compared to the National and World Health Organization (WHO) water quality standards.

\section{MATERIALS AND METHODS}

\section{Study area}

The present study was conducted in the Ain Zada Reservoir $\left(05^{\prime \prime} 80^{\prime} 36^{\circ} \mathrm{N}, 40^{\prime \prime}\right.$ $18^{\prime} 05^{\circ} \mathrm{E}$ ), a big dam located in a semiarid region in the Bou Sellam basin (Fig. 1), northeastern Algeria (Bordj Bou Arreridj City), $25 \mathrm{~km}$ west of Setif and $40 \mathrm{~km}$ east of Bordj Bou Arreridj. It is locating on wadi Bou Sellem and drains the site of a 2080 $\mathrm{km}^{2}$ watershed. It has a semi-arid climate and was constructed in 1986 with a dam height of $55 \mathrm{~m}$. The area has a semiarid Mediterranean climate, characterized by a relatively winter temperate and also hot and dry summer, the rainy season runs among September and May, announcing the end of the wet season. The Bou Sellam basin is characterized too by an inter annual variability of rainfall, where we note that much of the rain falls in this region were during a few weeks in the form of downpour, then great droughts ahead after these downpours. The average annual rain falls vary between 300 and $700 \mathrm{~mm}$. The Ain Zada reservoir is fed by Oued Bou Sellam, the reservoir stored a volume of water about $125 \mathrm{hm}^{3}$ and regulating a volume of $50 \mathrm{hm}^{3}$ per year to ensure the drinking and industrial water needs for the rapidly growing populations of Bordj Bou Arreridj and Setif cities (Mimeche and Biche, 2015; Ryma and Mouloud, 2018).
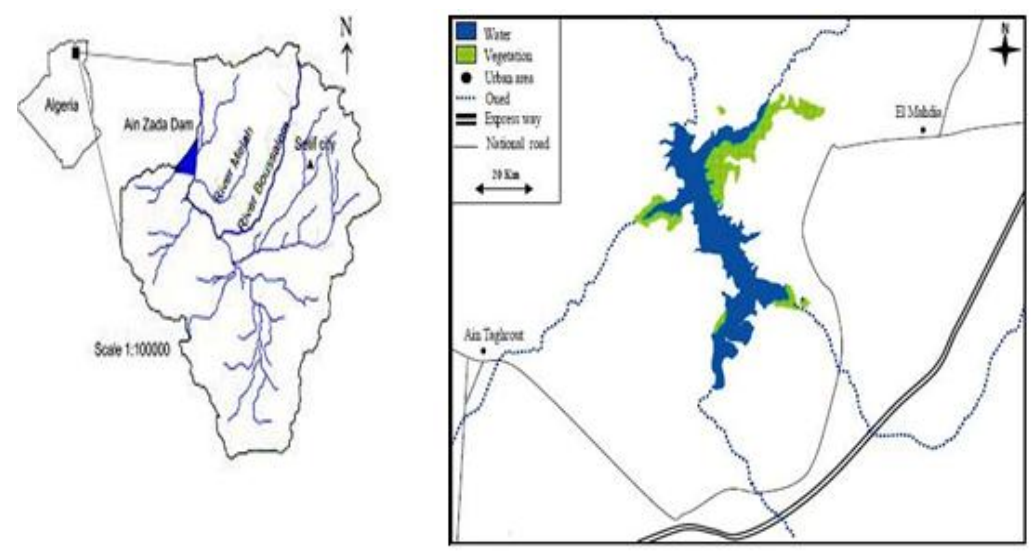

Fig. 1: Location of the study area. 


\section{Sampling}

The water samples were collected from four locations (Raw water, Water before treatment, Water after treatment, Tap water) of Ain Zada dam from November 2013 to April 2014. All the samples were collected in sterilized and phosphate free bottle. The procedures for the analysis followed standard methods of analysis of water and waste water. All chemicals used were of AR grade and instruments used for study were of best quality and highest accuracy (WHO, 1993; APHA, 1998).

\section{The physicochemical and bacteriological Analysis}

The physicochemical and bacteriological Analysis of water was carried out at the Algerian Water Laboratory (A.D.E.) of Bordj Bou Arreridj (BBA). All chemicals used were of analytical reagent grade, and doubly distilled water was used in the preparation of all solutions in the experiments.

\section{The physicochemical analysis}

Several physical and chemical parameters were studied in the dam water at each station. Prior to analysis, all instruments were calibrated according to manufacturer's recommendations. The temperature of the water samples was determined by using a thermometer, $\mathrm{pH}$ was determined using the ODYSSEY $\mathrm{pH}$ meter (model DR / 2500), which was used after it was calibrated with standard buffers 4.0, 7 and 10. Conductivity was determined using ODYSSEY portable conductivity meter. Total suspended solids, total dissolved solids and Dissolved Oxygen were estimated by TDS ODYSSEY meter (Trivedi, 1997). Determination of turbidity was done using Turbidimeter, in Nephelometric turbidity units (NTU). The chloride content in water was determined by volumetric titration using standard solution of silver nitrate $\left(0.1 \mathrm{molL}^{-1}\right)$ with potassium chromate $\left(\mathrm{K}_{2} \mathrm{CrO}_{4}\right)$ as an indicator (More's method) (Waters-Doughty, 1924; AOAC, 1984). A spectrophotometer ODYSSEY (Model DR / 2500), with $1 \mathrm{~cm}$ matching quartz cells were used for the absorbance measurements and then reads spectrophotometer at 420 $\mathrm{nm}$. Dry residue concentration determined by heating the samples at an oven at $105^{\circ}$ $\mathrm{C}$, for 24 hour, leave to cool for 15 minutes in the desiccator, weigh immediately and quickly, the results are given in $\mathrm{mg} / \mathrm{L}$.

Ammonium was determined by continuous flow method. The result is a greenish color that appears after one and half hour and indicates the presence of $\mathrm{NH}_{4}{ }^{+}$. A quantitative analysis is carried out by UV spectrophotometer at $655 \mathrm{~nm}$. The results are given directly in $\mathrm{mg} / \mathrm{L}$. Alkalinity of water samples were determined volumetrically by strong acid titration method. Bicarbonates $\left(\mathrm{HCO}_{3}{ }^{-}\right)$, TAC was determined by $\mathrm{pH}$ - metric method at the equivalent point (Zangen, 1962). Calcium $\left(\mathrm{Ca}^{2+}\right)$, Magnesium $\left(\mathrm{Mg}^{2+}\right)$ and Total Hardness $(\mathrm{TH})$, were analyzed by the standard EDTA $(0.01 \mathrm{M})$ titration method. Erichrome Black T was used as an indicator. Then, the solution was titrated with EDTA, until the last reddish tinge disappeared (the solution is normally blue) (APHA, 1999). Trace heavy metals i.e Iron, Manganese and Aluminum contents were determined by standards prescribed by (APHA, 1998) using Atomic Absorption Spectrometer (Perkin Elmer model A Analyst400).

\section{Bacteriological analysis}

The membrane filtration method of water analysis was used. Membrane filter of $47 \mathrm{~mm}$ and pore size $0.45 \mu \mathrm{m}$ were used according to recommendations by APHA AWWA (1998). 100mls each of water samples from six boreholes and five streams were filtered and the bacteria isolated and identified using the methods described by (Cheesbrough, 2000; Okorafor et al., 2012). 


\section{Statistical analysis}

Pearson Correlation Matrix and One-way analysis of variance (ANOVA) was utilized to investigate the inter-relationships between physico - chemical parameters. Alpha value for confidence interval (5\%). All statistical analyses of data were conducted using computer program: Stat Plus LE Analyst Soft Inc 6.3.0.0 and analysis tool pack in Microsoft Excel.

\section{RESULTS AND DISCUSSION}

\section{Physicochemical parameters}

Table 1 represents some physicochemical parameters of water samples collected from four locations (Raw water, Water before treatment, Water after treatment, Tap water) of Ain Zada dam during November 2013 to April 2014.

Table 1: The levels Physico-chemical parameters of the different types of water from the Ain Zada Dam to Bordj Bou Arreridj during Nov. 2013- April 2014.

\begin{tabular}{|c|c|c|c|c|c|}
\hline \multirow[t]{2}{*}{ Parameters } & \multicolumn{4}{|c|}{ Samples } & \multirow{2}{*}{$\begin{array}{c}\text { Limits } \\
\mathrm{WHO}, 2004\end{array}$} \\
\hline & Raw water & Water before treatment & Water after treatment & Tap water & \\
\hline Temperature ${ }^{\circ} \mathrm{C}$ & 14.89 & 14.89 & 15.05 & 16.13 & $<25$ \\
\hline $\mathrm{pH}$ & 7.87 & 7.88 & 7.47 & 6.74 & $6.5-8.5$ \\
\hline $\begin{array}{c}\text { Conductivity } \\
\mu \mathrm{s} / \mathrm{cm}\end{array}$ & 1262 & 1271 & 1273 & 1170 & 900 \\
\hline TDS (ppm) & 560 & 558 & 580 & 577 & 1000 \\
\hline Dry residue & 798 & 797 & 845 & 786 & 1000 \\
\hline Turbidity NTU & 11.75 & 11.36 & 1.51 & 1.47 & 5 \\
\hline $\begin{array}{c}\text { Dissolved } \\
\text { Oxygen }(\mathrm{mg} / \mathrm{L})\end{array}$ & 4.65 & 4.63 & 6.16 & 8.16 & $<4.3$ \\
\hline Nitrate $(\mathrm{mg} / \mathrm{L})$ & 2.52 & 2.52 & 2.89 & 3.23 & 50 \\
\hline Nitrite $(\mathrm{mg} / \mathrm{L})$ & 0.193 & 0.19 & 0.003 & 0.01 & $0.01-0.1$ \\
\hline $\begin{array}{c}\text { Phosphate } \\
\text { (mg/L) }\end{array}$ & 0.32 & 0.31 & 0.02 & 0.03 & 0.1 \\
\hline $\begin{array}{l}\text { Ammonium } \\
(\mathrm{mg} / \mathrm{L})\end{array}$ & 2.65 & 2.64 & 0.01 & 0.02 & 0.5 \\
\hline $\begin{array}{c}\text { Total Hardness } \\
(\mathrm{mg} / \mathrm{L})\end{array}$ & 58.58 & 57.67 & 59.67 & 63.34 & 500 \\
\hline Calcium (mg/L) & 41.3 & 41.3 & 42.41 & 40.96 & 100 \\
\hline $\begin{array}{c}\text { Magnesium } \\
(\mathrm{mg} / \mathrm{L})\end{array}$ & 31.44 & 31.42 & 32.05 & 32.47 & 50 \\
\hline Sodium & 139 & 139 & 141 & 140 & 200 \\
\hline $\begin{array}{l}\text { Potassium } \\
(\mathrm{mg} / \mathrm{L})\end{array}$ & 7.6 & 7.6 & 7.4 & 7.1 & 12 \\
\hline Chloride (mg/L) & 211.11 & 211.16 & 230.74 & 243.95 & 250 \\
\hline Sulfate (mg/L) & 160.09 & 159.76 & 162.97 & 158.28 & 250 \\
\hline $\begin{array}{c}\text { Bicarbonate } \\
\mathrm{HCO}_{3}(\mathrm{mg} / \mathrm{L})\end{array}$ & 203.8 & 203.8 & 184.9 & 162.4 & 400 \\
\hline $\mathrm{TAC}(\mathrm{mg} / \mathrm{L})$ & 16.71 & 16.71 & 15.15 & 13.3 & 50 \\
\hline Iron & 0.27 & 0.27 & 0.11 & 0.1 & 0.3 \\
\hline Manganese & ND & ND & ND & 0.018 & 0.1 \\
\hline Aluminum & ND & ND & 0.007 & 0.09 & 0.2 \\
\hline
\end{tabular}




\section{Water temperature and pH:}

Temperature is an important parameter for aquatic environment; it is governed by physical, chemical and biochemical properties (Taiwo et al., 2012). Temperature is the main factor which affects almost all physico-chemical equilibriums and biological reactions (Delpla et al., 2009). It can influence the $\mathrm{pH}$, dissolved oxygen, redox potentials and microbial activity (Park et al., 2010). The obtained results showed that the temperature ranged between 14.89 to $16.13{ }^{\circ} \mathrm{C}$ (Figure 2). Arain et al., (2009), reported that there is a close relation between the atmospheric temperature and water temperature, air temperature is one of the most important ecological factors which control the physiological behavior of the aquatic system and distribution of the microorganisms.

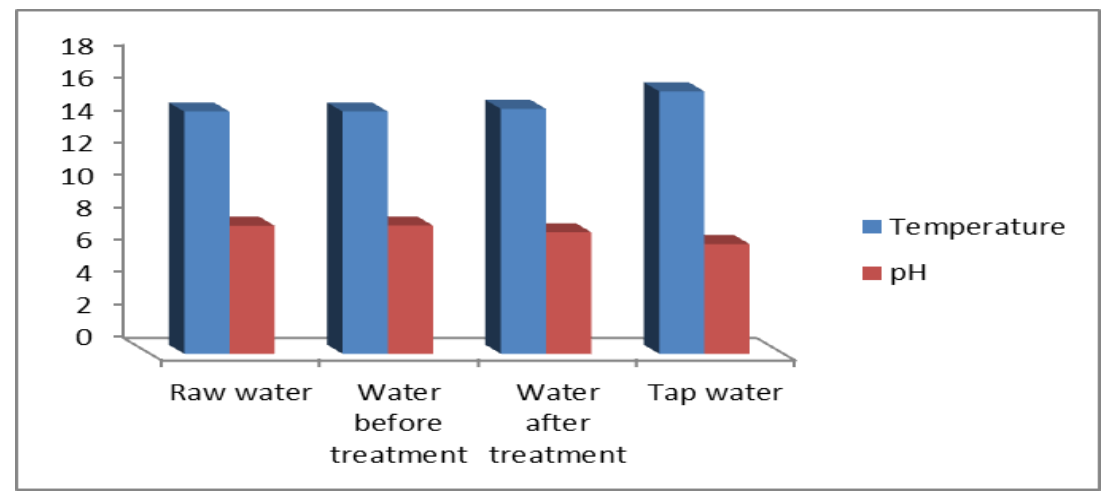

Fig. 2: Mean values of water temperature and $\mathrm{pH}$ from different types of water from the Ain Zada Dam to Bordj Bou Arreridj during Nov. 2013-April 2014

The $\mathrm{pH}$ of water is a reflection of the degree of acidity ( $\mathrm{pH}$ lower than 7) or alkalinity $(\mathrm{pH}$ greater than 7). The fact that the $\mathrm{pH}$ of most unpolluted water lies between 6.5 and $8.5 \mathrm{pH}$ is an important operational water quality parameter (WHO, 2011). The taste of water, its corrosiveness and solubility and speciation of metal ions are all influenced by $\mathrm{pH}$. At low $\mathrm{pH}$, water may taste sour while at high $\mathrm{pH}$ water taste bitter or soapy (DWA, 2006). The $\mathrm{pH}$ values didn't show fluctuations over the study period. In this research, the average of $\mathrm{pH}$ on the sampling sites was found between 6.74 and 7.87. The maximum $\mathrm{pH}$ value, 7.87, was recorded in the raw water source. The water $\mathrm{pH}$ values in most sampling points were found within the slight alkaline side (Fig. 2).

The $\mathrm{pH}$ value is influenced by the organic and inorganic compounds present in water. Any alteration in water $\mathrm{pH}$ is accompanied by the change in other physicochemical parameters. $\mathrm{pH}$ maintenance is one of the most important attributes of any aquatic system since all biochemical activities depend on surrounding water $\mathrm{pH}$. Maximum values at raw water may be due to the increased in photosynthesis process of the algal blooms resulting into the precipitation of calcium and magnesium carbonates from bicarbonates causing higher alkalinity.

\section{Conductivity, TDS and Dry residue}

Conductivity, TDS and Dry residue at different sites were shown at Fig. 3. Conductivity is the electrical property of water, and depends on the ions present in the water - their concentration, mobility and the charge, as well as of the temperature at which the conductivity is measured. The maximum allowed value of conductivity of drinking water is up to $1000 \mu \mathrm{S} \mathrm{cm}^{-1}$ (Nebojša Pantelić et al., 2017). The minimum conductivity was measured in Tap water $1170 \mu \mathrm{S} \mathrm{cm}^{-1}$ and the maximum in water after treatment $1273 \mu \mathrm{S} \mathrm{cm}^{-1}$ (Figure 3). The obtained values were found above the 
recommended value of WHO $(900 \mu \mathrm{s} / \mathrm{cm})$, and SON $(1000 \mu \mathrm{s} / \mathrm{cm})(\mathrm{WHO}, 2004 ; \mathrm{SON}$, 2003). This measures the ability of water to conduct electricity which depends on the concentration of dissolved substances and temperature (Taiwo et al., 2012, Roopavathi et al., 2016).

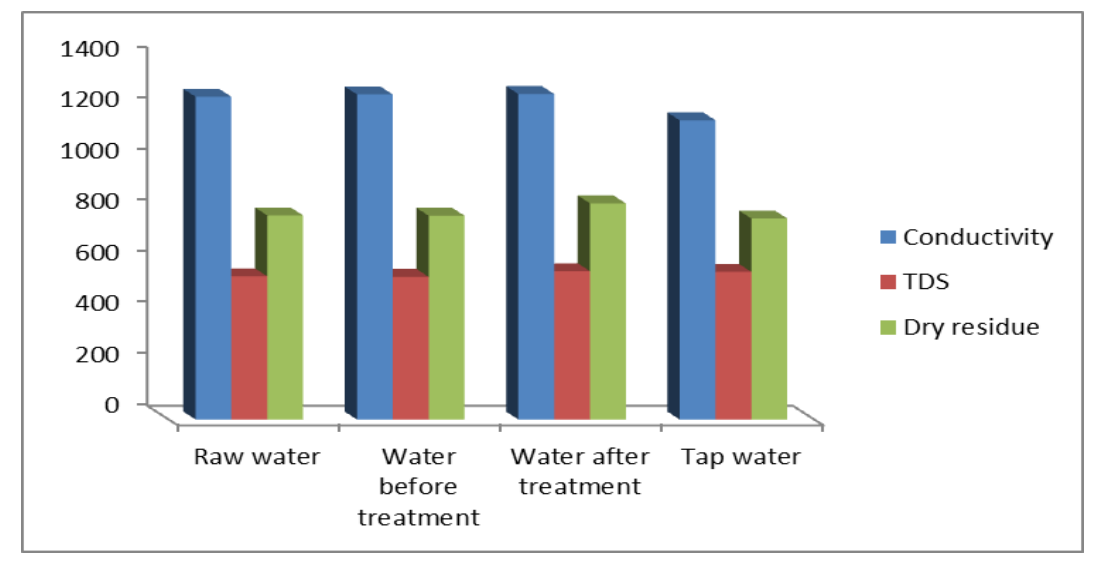

Fig. 3: Mean values of Conductivity, TDS and Dry residue from different types of water from the Ain Zada Dam to Bordj Bou Arreridj during Nov. 2013-April2014.

The level of TDS decides the quality of drinking water and since it is an important factor to aquatic life in keeping the cell density balanced. TDS and Dry residue of the samples ranged from $558 \mathrm{mg} / \mathrm{L}$ at Water before treatment $-580 \mathrm{mg} / \mathrm{L}$ at Water after treatment for TDS and from $786 \mathrm{mg} / \mathrm{L}$ at Tap water to $845 \mathrm{mg} / \mathrm{L}$ at Water after treatment. WHO is less than $1000 \mathrm{mg} / \mathrm{L}$; Water with high TDS has normally affected the taste and causes the high alkalinity or hardness. The TDS concentration is a secondary drinking water standard, therefore, is regulated because it is more of a visual rather than a health hazard. The values of total dissolved solid and dry residue were considered high. These high values may be due to ground water pollution by waste waters which may originate naturally or introduced through human activities (Taiwo et al., 2012).

\section{Turbidity and Dissolved Oxygen DO}

Turbidity in water is due to suspend and colloidal matter such as clay, silt, finely divided organic and inorganic matter, plankton and other microscopic organisms (Roopavathi et al., 2016). The turbidity of the samples lies between 1.47 NTU to 11.75 NTU in the study area (Fig. 4). Maximum permissible limit of turbidity in drinking water is 5 NTU as suggested by WHO (2004), only raw water and Water before treatment samples exceed this limit.

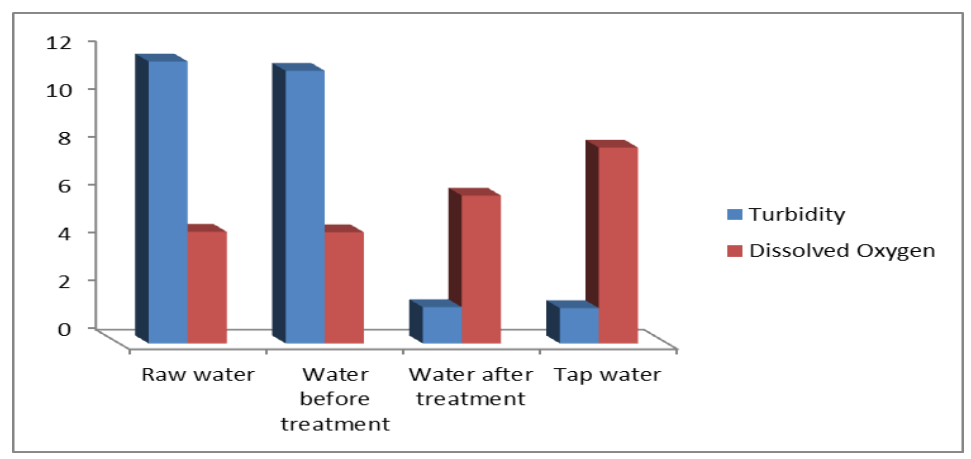

Fig. 4: Mean values of Turbidity and Dissolved Oxygen DO from different types of water from the Ain Zada Dam to Bordj Bou Arreridj during Nov. 2013-April2014 
DO concentration is one of the most important parameter to indicate water purity. The importance of DO in aquatic ecosystem brings out various biochemical changes and it influence metabolic activities of organisms. In this research, the DO was found between 4.63 to $8.16 \mathrm{mg} / \mathrm{L}$ above normal of $<4.3 \mathrm{mg} / \mathrm{L}$ as recommended by WHO. The quantity of DO in water is directly or indirectly dependent on water temperature, partial pressure of air. Similar results were observed by Gulumbe et al. (2016) who reported that DO in water is largely dependent on important environmental factors like the temperature.

\section{Nitrate and Nitrite}

The presence of nitrates in water samples is suggestive of some bacterial action and other biological activities. Nitrate concentration in this research was found to vary from 2.52 to $3.23 \mathrm{mg} / \mathrm{L}$ (Fig. 5), which found within the $50 \mathrm{mg} / \mathrm{L}$ of WHO specification. Nitrate concentration depends on the activity of nitrifying bacteria which in turn get influenced by the presence of DO. This may be caused by the higher phytoplanktonic production, decaying macrophytes and concentration of nutrients due to the evaporation of water with subsequent increase in nitrate value. These facts have also been stressed by Majumder et al., (2006); and Agarwal and Rajwar, (2010) in their observations. The decrease in nitrate content was probably due to its utilization as nutrient by the algal community as it has been evidenced by the massive growth of algae. Its value in the samples indicates pollution free, good water quality wise and suitable for drinking purpose.

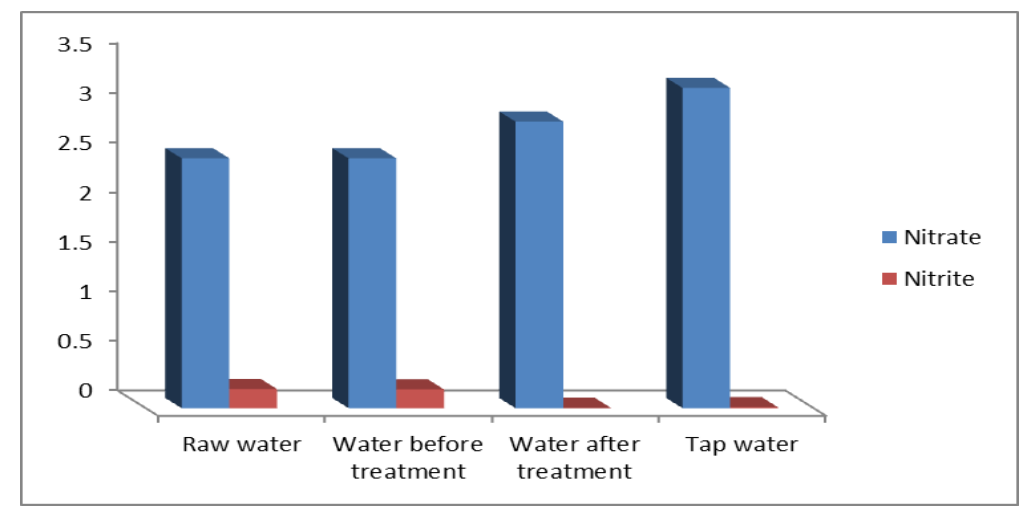

Fig. 5: Mean values of Nitrate and Nitrite from different types of water from the Ain Zada Dam to Bordj Bou Arreridj during Nov. 2013-April2014.

While the increase in the nitrite because either ammonium oxidation or reduction of nitrate by denitrification (Mebarkia et al., 2017). All the water samples had traces of nitrite $0.003-0.193 \mathrm{mg} / \mathrm{L}$ (Figure 5).WHO required that Nitrite should be negligible because it forms $\mathrm{N}$-nitroso compounds with Nitrogen in human stomach and accumulation of these act as potent carcinogens, Nitrite also has the ability to cause infant Methaemoglobin anaemia or blue baby syndrome (WHO, 1999).

\section{Phosphate and Ammonium}

During the present investigation, phosphate values were found between 0.020 , $0.03 \mathrm{mg} / \mathrm{L}$ at treated and tap water to $0.32 \mathrm{mg} / \mathrm{L}$ at raw water as shown in Fig. 6 . WHO (1993) has fixed it to be $0.1 \mathrm{mg} / \mathrm{L}$. If level becomes too high, plant growth can accelerate resulting in the dense growth of algae and plants in the water body. Accelerated and uncontrolled plant growth impairs fishing, boating and other recreational uses of natural water (Choudhary et al., 2014). The phosphate range in the Tap water of the present study was found within the permissible limit prescribed by WHO hence this water is suitable for drinking purposes. 


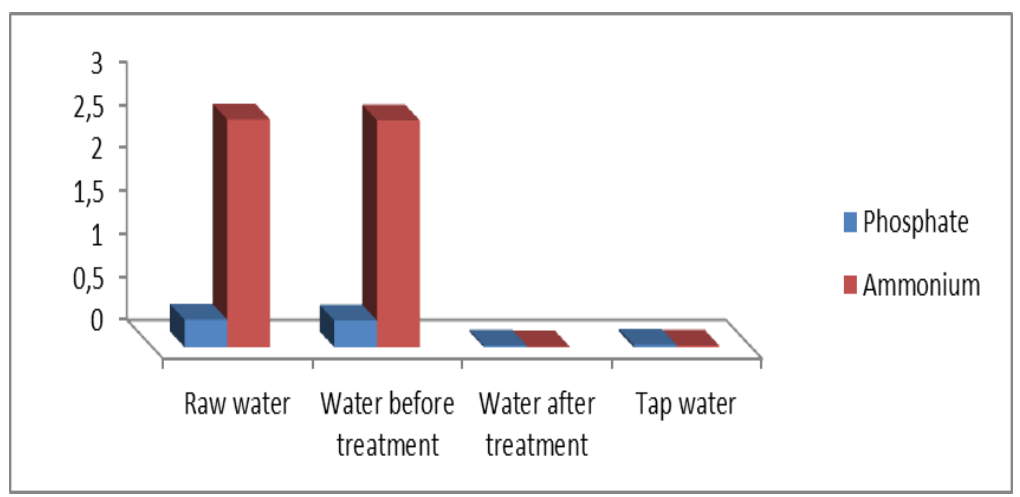

Fig. 6: Mean values of Phosphate and Ammonium from different types of water from the Ain Zada

Dam to Bordj Bou Arreridj during Nov. 2013-April2014.

Ammonia is a biologically active compound found in most waters as a normal biological degradation product of nitrogenous organic matter (protein). In water ammonia reacts to form ammonium $\left(\mathrm{NH}_{4}{ }^{+}\right)$and hydroxyl $\left(\mathrm{OH}^{-}\right)$ions. When the $\mathrm{pH}$ increase above 7.2, some free $\mathrm{NH}_{3}$ remains and increases with increasing $\mathrm{pH}$. It has been known that ammonia $\left(\mathrm{NH}_{3}\right)$ is toxic to fish and its toxicity increases with increasing $\mathrm{pH}$ and temperature of the water (Medeiros et al., 2016). According to WHO, the maximum allowed presence of ammonia in drinking water is $0.5 \mathrm{mg} \mathrm{L}^{-1}$ (WHO, 1993). Only water samples from raw and untreated water contained higher level of ammonia $\left(0.5 \mathrm{mg} \mathrm{L}^{-1}\right)$ while the values of the other samples were far below the maximum permissible value (Table 1).

\section{Total Hardness, Calcium and Magnesium}

The hardness of water is due to dissolved calcium and magnesium salts from soil and aquifer minerals containing limestone or dolomite (Roopavathi et al., 2016). As in figure 7, the total hardness of the samples ranged between $57.67-63.34 \mathrm{mg} / \mathrm{L}$, while WHO standards permit any value less than $500 \mathrm{mg} / \mathrm{L}$. In all samples of a study area, the total hardness were found not exceeded and beyond the maximum acceptable limit. Maximum permissible limit of calcium and magnesium in drinking water is $100 \mathrm{mg} / \mathrm{L}$ and $50 \mathrm{mg} / \mathrm{L}$ as suggested by WHO limit. In the area studied the content of calcium and magnesium in water ranged from $40.96-42.41 \mathrm{mg} / \mathrm{L}$ and 31.42-32.47 mg/L, respectively Fig. 7.

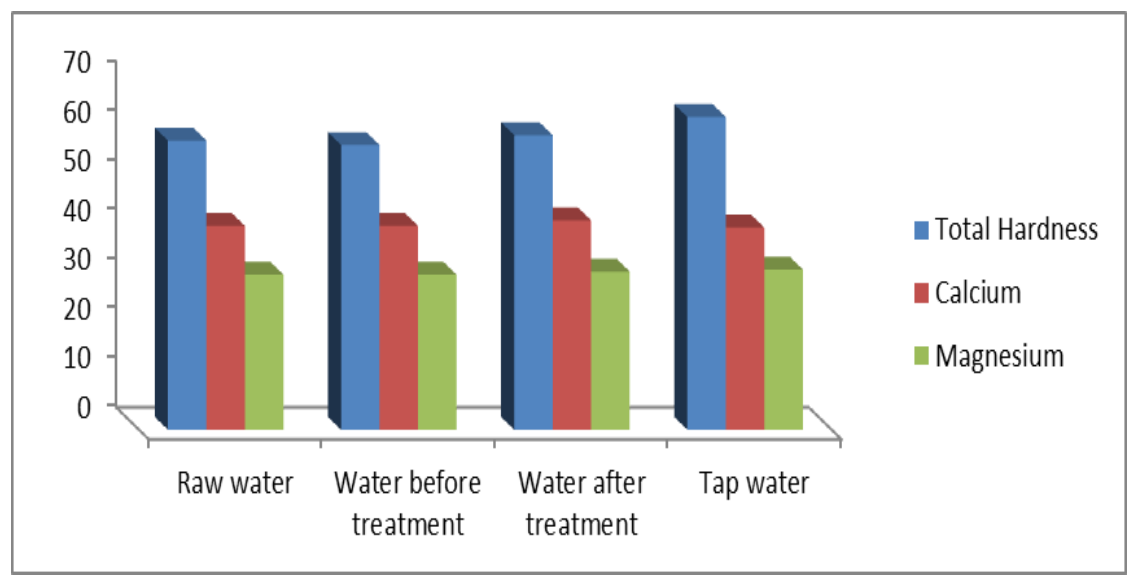

Fig. 7: Mean values of Total Hardness, Calcium and Magnesium from different types of water from the Ain Zada Dam to Bordj Bou Arreridj during Nov. 2013-April2014.

Both calcium and magnesium are essential for human body development and also for normal function. Inadequate intake of either nutrient can impair health. 
Recommended daily intakes of each element have been set at national and international levels. As calcium is also a part of bones and teeth, it also plays a role in neuromuscular excitability (decreases it). Magnesium is essential as co-factor for enzyme activity including glycolysis, ATP metabolism, and transport of elements such as $\mathrm{Na}$, K and $\mathrm{Ca}$ through membranes (WHO, 2009; Roopavathi et al., 2016).

\section{Sodium and Potassium}

Potassium and sodium maintain the normal osmotic pressure in cells. Potassium is a cofactor for many enzymes and is required for the secretion of insulin, creatinine phosphorylation' carbohydrate metabolism and protein synthesis.

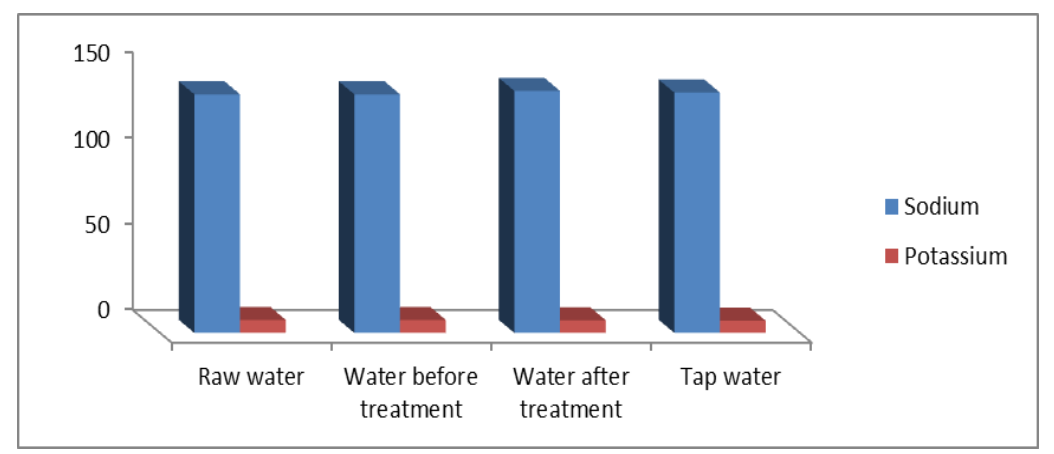

Fig. 8: Mean values of Sodium and Potassium from different types of water from the Ain Zada Dam to Bordj Bou Arreridj during Nov. 2013-April2014.

Minimum (139 mg/L) and maximum (141 mg/L) Sodium (Na) content was observed from raw and untreated water samples respectively (Table 1 and Fig. 8). The acceptable limit for $\mathrm{Na}$ is $200 \mathrm{mg} / \mathrm{L}$ according to WHO limit (Table 2). Potassium is an important cation and plays a vital role in intermediately metabolism. $\mathrm{K}^{+}$is an essential nutrient for both plant and human life. Potassium (K) content of water samples varied from $7.1 \mathrm{mg} / \mathrm{L}$ at Tap water to $7.6 \mathrm{mg} / \mathrm{L}$ at raw water (Table 1, Fig. 8). All the water samples $(100 \%)$ contained K content lower than permissible limit i.e. 20mg/L (Table 1). Sodium and Potassium affect on desirability, odor and taste of water (Rout, and Sharma 2011).

\section{Chloride and Sulfate}

Chloride values were found between 211.11 to $243.95 \mathrm{mg} / \mathrm{L}$ (Fig. 9) which is still below the WHO $250 \mathrm{mg} / \mathrm{L}$ specification. Although the concentration is not high, it is an indicator of pollution due to organic waste of animal origin.

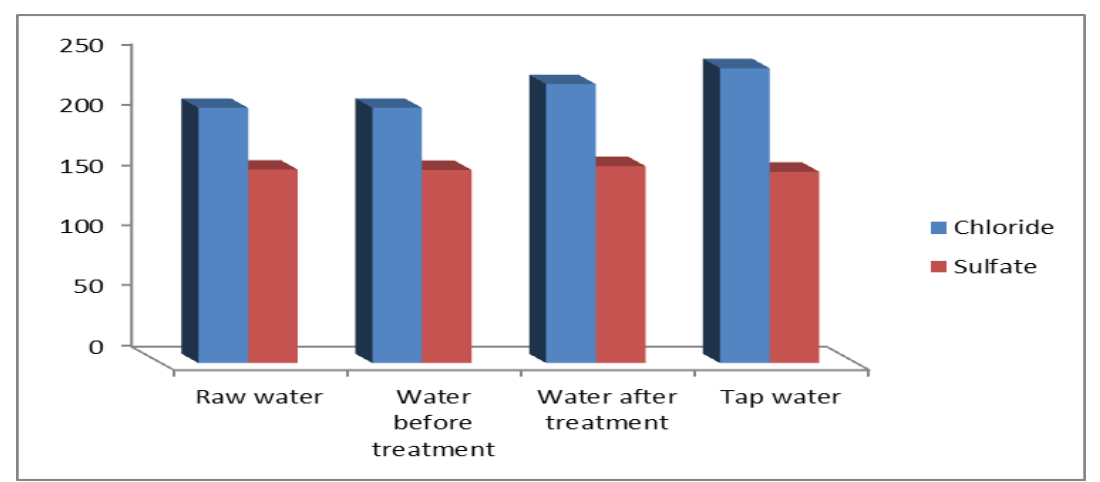

Fig. 9. Mean values of Chloride and Sulfate from different types of water from the Ain Zada Dam to Bordj Bou Arreridj during Nov. 2013-April2014

Sulphate is one of the least toxic anions of which WHO does not have any recommended value for drinking water, but catharsis, dehydration and gastrointestinal irritation have been linked to high sulphate concentrations in drinking 
water (Gulumbe et al., 2016). WHO (2011) therefore suggests an urgent action by health authorities when sulphate in drinking water exceeds $250 \mathrm{mg} / \mathrm{L}$. Sulphate occurs naturally in water as a result of leaching from gypsum and other common minerals (Kamal et al., 2007). Discharge of industrial wastes and domestic sewage tends to increase its concentration (Gulumbe et al., 2016). Concentration of sulphate in this research which ranged from 158.28 to $160.09 \mathrm{mg} / \mathrm{L}$ may be accompanied with the different types of water quality.

\section{Bicarbonate and Total Acidity (TAC)}

The Bicarbonate $\left(\mathrm{HCO}_{3}{ }^{-}\right)$ion is the principal alkaline constituent in almost all water supplies. Three carbonate species $\left(\mathrm{H}_{2} \mathrm{CO}_{3} \cdot \mathrm{HCO}_{3}{ }^{-}\right.$and $\left.\mathrm{CO}_{3}{ }^{-2}\right)$ contribute to total alkalinity، their relative proportions being dependent on $\mathrm{pH}$ and temperature. At nearneutral values of $\mathrm{pH}$ c dissolved bicarbonate $\left(\mathrm{HCO}_{3}{ }^{-}\right)$is the dominant ion. The desirable limit of bicarbonate alkalinity in portable water is $400 \mathrm{mg} / \mathrm{L}$, the minimum and maximum Bicarbonate values of water were observed on all sites, they found between 162.4 and $203.8 \mathrm{mg} / \mathrm{L}$ at Tap and Raw water respectively (Fig. 10). The bicarbonate alkalinity values of all samples were found within the permissible limit of 400mg/L (Roopavathi et al., 2016).

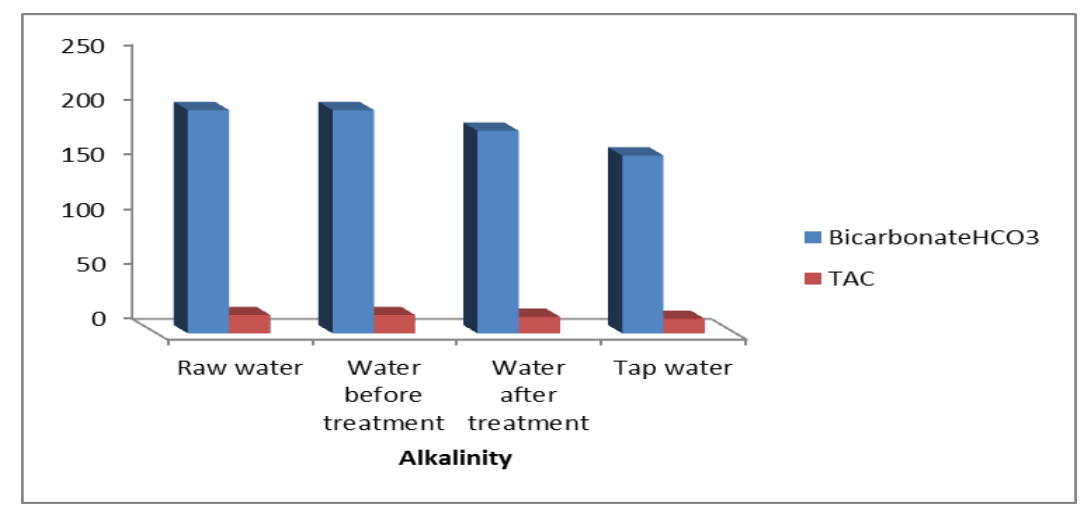

Fig. 10: Mean values of Bicarbonate and Total Acidity (TAC) from different types of water from the Ain Zada Dam to Bordj Bou Arreridj during Nov. 2013-April2014.

Total acidity (TAC) values were observed, that ranging between 13.3 to 16.71 $\mathrm{mg} / \mathrm{L}$ as $\mathrm{CaCO}_{3}$. All samples were found within the permissible limits of WHO limit $(50 \mathrm{mg} / \mathrm{L})$. Hence the water must not be treated before its use for drinking and construction purpose.

\section{Iron, Manganese and Aluminum}

Iron and Manganese are an abundant metal found in the Earth's crust. It is naturally present in water but can also be present in drinking water from the use of iron coagulants or the corrosion of steel and cast iron pipes during water distribution. Iron is an essential element in human nutrition. WHO (2004) states that, values of up to $0.3 \mathrm{mg} / \mathrm{L}$. The studied sample ranged from 0.1 to $0.27 \mathrm{mg} / \mathrm{L}$, so it do not present a hazard to health (EPA, 2014). High levels of manganese also cause objectionable tastes in the water but there are no particular toxicological connotations. The WHO recommends a guideline value of $0.1 \mathrm{mg} / \mathrm{L}$ (Fig. 11). The average manganese of water in samples varied between below the limit of detection to $0.018 \mathrm{mg} / \mathrm{L}$.

Aluminum is one of the trace inorganic metals present in drinking water. In addition to the naturally occurring $\mathrm{Al}$ in raw waters' use of Al-based coagulants often leads to an increase in treated water $\mathrm{Al}$ concentrations, though can be naturally present in some waters. WHO (2004) has proposed a guideline value of $0.2 \mathrm{mg} / \mathrm{L}$. Aluminum levels ranged between the below the limit of detection to $0.09 \mathrm{mg} / \mathrm{L}$ in the 
studied samples, which still lower than the permissible limits (Letterman and Driscoll, 1994).

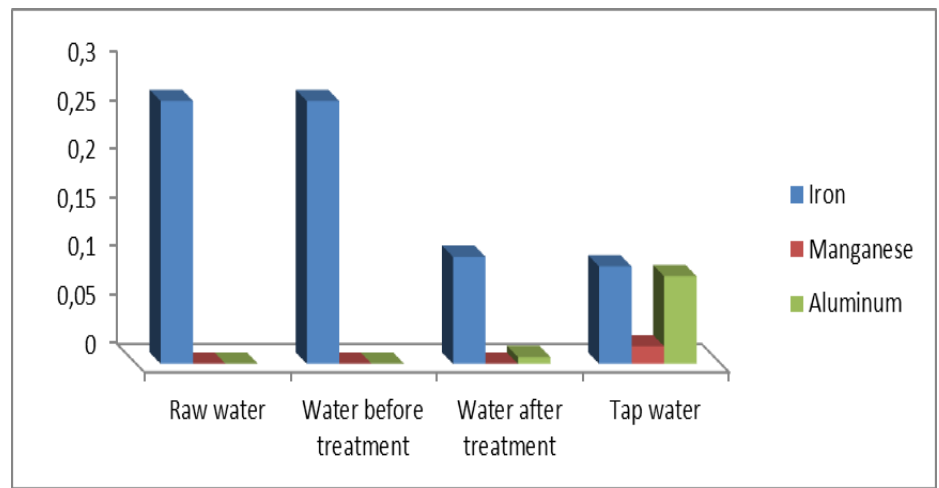

Fig. 11: Mean values of Iron, Manganese and Aluminum from different types of water from the Ain Zada Dam to Bordj Bou Arreridj during Nov. 2013-April2014

\section{Physico-chemical Correlation}

The correlation coefficient is commonly used to estimate the relationship between two variables. It is a simple statistical tool to show the degree of connection between the various variables. When, various water quality parameters of water samples were correlated (Table 2). At Alpha value for confidence interval (5\%). Total hardness showed high significant positive correlation with DO, Nitrate, and temperature $(0.979,0.961$ and 0.973$)$ but negative significance with most parameters. TDS concentration is positively influenced by DO (0.812), Total hardness $(0.723)$ and Nitrate (0.862) with significant. Chlorides is normally the most dominant anion in water it showed significant positive with Total hardness (0.941), magnesium (0.999), Sodium (0.708), and DO (0.985). TDS significantly correlated with DO (0.812) and Total hardness (0.723) but it also relate with Nitrate, phosphate and ammonium but they are insignificant. Calcium and Sodium positively correlated with Sulphate $(0.986,0.602)$ respectively.

Table 2: Significant correlation coefficients values among the physic-chemical water quality parameters at different types of water from the Ain Zada Dam to Bordj Bou Arreridj during Nov. 2013-April2014

\begin{tabular}{|c|c|c|c|c|c|c|c|c|c|c|c|c|}
\hline & pH & Temp. & Conduc & TDS & $\begin{array}{c}\text { Dry } \\
\text { residue }\end{array}$ & Turbidity & D.O. & Nitrate & Nitrite & Phosphate & Ammon & $\begin{array}{c}\text { Total } \\
\text { Hardness }\end{array}$ \\
\hline pH & 1.000 & & & & & & & & & & & \\
\hline Temp. & $-0.971 *$ & 1.000 & & & & & & & & & & \\
\hline Conduc & 0.908* & $-0.979 *$ & 1.000 & & & & & & & & & \\
\hline TDS & $-0.764 *$ & $0.590 *$ & -0.433 & 1.000 & & & & & & & & \\
\hline $\begin{array}{l}\text { Dry } \\
\text { residue }\end{array}$ & 0.182 & -0.409 & $0.570 *$ & 0.492 & 1.000 & & & & & & & \\
\hline Turbidity & 0.831* & $-0.677^{*}$ & $0.524 *$ & $-0.988 *$ & -0.393 & 1.000 & & & & & & \\
\hline D. 0. & $-0.996 *$ & $0.950 *$ & $-0.872 *$ & $0.812 *$ & -0.103 & $-0.873 *$ & 1.000 & & & & & \\
\hline Nitrate & $-0.985 *$ & $0.917^{*}$ & $-0.823 *$ & $0.862 *$ & -0.011 & $-0.914 *$ & $0.995^{*}$ & 1.000 & & & & \\
\hline Nitrite & $0.815^{*}$ & $-0.655^{*}$ & $0.500 *$ & $-0.993 *$ & -0.420 & 0.999* & $-0.858 *$ & $-0.902 *$ & 1.000 & & & \\
\hline Phosphate & 0.816* & $-0.657 *$ & $0.501 *$ & $-0.991 *$ & -0.417 & 0.999* & $-0.859 *$ & $-0.903 *$ & $0.999 *$ & 1.000 & & \\
\hline Ammon & $0.829 *$ & $-0.673^{*}$ & $0.521 *$ & $-0.991 *$ & -0.398 & 0.999* & $-0.870 *$ & $-0.912 *$ & 0.999* & $0.999 *$ & 1.000 & \\
\hline $\begin{array}{c}\text { Total } \\
\text { Hardness }\end{array}$ & $-0.987 *$ & 0.973* & $-0.933 *$ & $0.723 *$ & -0.239 & $-0.781 *$ & $0.979 *$ & 0.961* & $-0.765^{*}$ & $-0.765^{*}$ & $-0.782^{*}$ & 1.000 \\
\hline
\end{tabular}


Table 2 Continue

\begin{tabular}{|c|c|c|c|c|c|c|c|c|c|c|c|}
\hline & $\mathrm{Ca}$ & $\mathrm{Mg}$ & $\mathrm{Na}$ & $\mathrm{K}$ & $\mathrm{Cl}$ & $\mathrm{SO}_{4}$ & $\mathrm{HCO}_{3}$ & TAC & $\mathrm{Fe}$ & Mn & Al \\
\hline $\mathrm{Ca}$ & 1.000 & & & & & & & & & & \\
\hline $\mathbf{M g}$ & 0.015 & 1.000 & & & & & & & & & \\
\hline $\mathrm{Na}$ & $0.717^{\star}$ & $0.707^{\star}$ & 1.000 & & & & & & & & \\
\hline $\mathbf{K}$ & 0.184 & $-0.979^{\star}$ & $-0.552^{\star}$ & 1.000 & & & & & & & \\
\hline $\mathrm{Cl}$ & 0.016 & 0.999* & $0.708^{\star}$ & $-0.979^{\star}$ & 1.000 & & & & & & \\
\hline $\mathrm{SO}_{4}$ & $0.986^{\star}$ & -0.133 & $0.602^{\star}$ & 0.329 & -0.133 & 1.000 & & & & & \\
\hline $\mathrm{HCO}_{3}$ & 0.126 & $-0.989^{\star}$ & $-0.601^{\star}$ & $0.998^{\star}$ & $-0.989^{\star}$ & 0.273 & 1.000 & & & & \\
\hline TAC & 0.125 & $-0.990^{\star}$ & $-0.601^{\star}$ & $0.998^{\star}$ & $-0.989^{\star}$ & 0.272 & 1.000 & 1.000 & & & \\
\hline $\mathrm{Fe}$ & -0.311 & $-0.955^{\star}$ & $-0.885^{\star}$ & $0.876^{\star}$ & $-0.955^{\star}$ & -0.164 & $0.903^{\star}$ & $0.904^{\star}$ & 1.000 & & \\
\hline Mn & $-0.561^{\star}$ & $0.818^{\star}$ & 0.174 & $-0.916^{\star}$ & $0.817^{\star}$ & $-0.678^{\star}$ & $-0.891^{\star}$ & $-0.891^{\star}$ & $-0.611^{\star}$ & 1.000 & \\
\hline Al & -0.497 & 0.859 & 0.247 & $-0.944^{\star}$ & $0.858^{\star}$ & $-0.621^{*}$ & $-0.923^{\star}$ & $-0.922^{*}$ & $-0.669^{*}$ & $0.997^{\star}$ & 1.000 \\
\hline
\end{tabular}

*Indicates the significance $(\mathrm{p}>0.05)$, without a star are near significant

\section{Bacteriological analysis}

An important indicator of water quality is the number of bacteria present in the water. Though it would be difficult to determine the presence of all bacteria in a sample, certain types of microorganisms can serve as indicators of pollution (Nkamare et al., 2012). Chief among these are Total coliform, total ger, E. coli, Fecal Streptococci and Clostridium Sulf-Red were studied at different samples from the study area (Fig. 12).

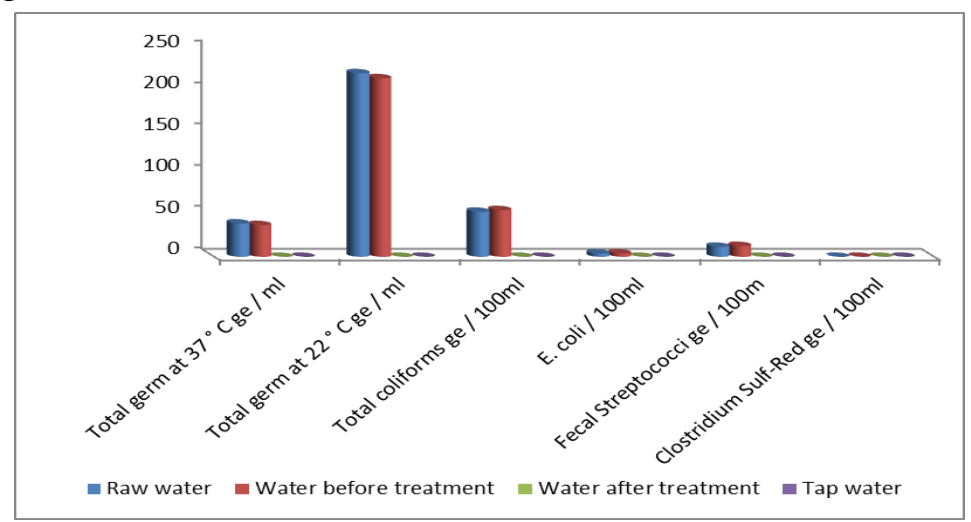

Fig. 12: Mean values of bacteriological count from different types of water from the Ain Zada Dam to Bordj Bou Arreridj during Nov. 2013-April2014.

Not all bacteria present in water are harmful but it is the kind of specific microorganisms which are pathogenic cause water borne diseases. Their presence in water indicates contamination of water supply with fecal matter. Coliforms are the major microbial indicators for monitoring water quality. They are commonly found in intestinal tract of men and animals and considered as indicator organisms, used all over the world to establish the degree of faecal pollution in water (Singh et al., 2017). From table 3, the results of bacteriological analysis after treatment and tap water appear consistent supplies of safe and wholesome water with low microbial load and do not need for another treatment of the drinking water (Deutsch, 2003). The zero (0) bacteriological count from after treatment and tap water may be due to routine treatment of such sources of drinking water. This result showed that these sites met the WHO standard for drinking water $(\leq$ zero Cfu/100ml). The presence and high number of counts in raw and before treatment water samples analysed showed that there were focally contaminated (Okorafor, et al., 2012). 
Table 3: Mean values of bacteriological count from different types of water from the Ain Zada Dam to Bordj Bou Arreridj during Nov. 2013-April2014

\begin{tabular}{|c|c|c|c|c|c|}
\hline \multirow[t]{2}{*}{ bacteriological count } & \multicolumn{4}{|c|}{ Samples } & Limits \\
\hline & $\begin{array}{l}\text { Raw } \\
\text { water }\end{array}$ & $\begin{array}{l}\text { Water before } \\
\text { treatment }\end{array}$ & $\begin{array}{l}\text { Water after } \\
\text { treatment }\end{array}$ & $\begin{array}{c}\text { Tap } \\
\text { water }\end{array}$ & $\begin{array}{l}\text { WHO } \\
\text { limit }\end{array}$ \\
\hline Total germ at $37^{\circ} \mathrm{C}$ ge $/ \mathrm{ml}$ & 40 & 38 & 0 & 0 & 0 \\
\hline Total germ at $22^{\circ} \mathrm{C}$ ge $/ \mathrm{ml}$ & 220 & 214 & 0 & 0 & 0 \\
\hline Total coliforms ge / 100ml & 54 & 56 & 0 & 0 & 0 \\
\hline E. coli / 100ml & 4 & 4 & 0 & 0 & 0 \\
\hline Fecal Streptococci ge / 100m & 12 & 13 & 0 & 0 & 0 \\
\hline $\begin{array}{l}\text { Clostridium Sulf-Red ge / } \\
100 \mathrm{ml}\end{array}$ & 0 & 0 & 0 & 0 & 0 \\
\hline
\end{tabular}

\section{CONCLUSION}

The present work is an attempt to identify and assess different sources of contamination to drinking water. The physico-chemical analysis reveals the present status of drinking after treatment and tap water is suitable for drinking purposes except in raw water, Water before treatment. The quality of physico-chemical falls within the standard limits of WHO standards. Raw water and Water before treatment has been contaminated by microorganisms and they were bacteriologically unsafe for drinking purposes. Presence of coliform in drinking water supplies may be either due to contamination by sewage water through domestic and industrial sources. Water sources must be protected from contamination by human and animal waste, which contains hazardous microbes. A regular monitoring of water quality is needed to protect if further polluted. Water quality should be controlled in order to minimize acute problem of water related diseases, which are endemic to the health of man.

\section{COMPETING INTERESTS}

Authors have declared that no competing interests exist.

\section{ACKNOWLEDGEMENT}

Authors would like to express their gratitude to Algerian Water Laboratory (A.D.E.) of Bordj Bou Arreridj for their technical support.

\section{REFERENCES}

Agarwal, A. K. and Rajwar, G. S. (2010). Physico-chemical and microbiological study of Tehri Dam reservoir, Garhwal Himalaya, India. Journal of American Science 6(6): 65-71.

Amanatidou, E.; Adamidou K.; Trikoilidou E.; Katsiouli, F.; Patrikaki, O. and Tsikritzis, L. (2007). Physicochemical and microbiological characteristics of the potable water supply sources in the area of Kozani, Western Macedonia, Desalination, 213: 1-8.

Aminur Rahman, M. D.; Monirul Islam, M.D. and Firoz Ahmed, A. D. (2015). Physico-chemical and bacteriological analysis of drinking tube-well water from some primary school, Magura, Bangladesh to evaluate suitability for students. Int. Journal of Applied Sciences and Engineering Research, 4(5): 735 - 749.

ANB BBA (Agence National des Barrages Borj Bou Arreridj) (2013). Données des caractéristiques techniques du Barrage Ain Zada. 
APHA - AWWA, (1998). Standard Methods for the Examination of Water and Waste- water, $19^{\text {th }}$ Ed. American Publication Health Association, Washington, pp. 136.

APHA (American Public Health Association), (1999). Standard Methods for the Examination of Water and Wastewater.

Arain, M.B.; Kazi, T.G; Baig, J.A.; Jamali, M.K.; Afridi, H.I.; Shah, A.Q.; Jalbani, N. and Sarfraz, R.A. (2009). Determination of arsenic levels in lake water, sediment, and foodstuff from selected area of Sindh, Pakistan: Estimation of daily dietary intake. Food and Chemical Toxicology (2009) 47 (1): 242-248.

Arora, D.R. and Arora, B. (2008). Bacteriology of water, milk and air. Text book of microbiology (3rd edition). CBS Publishers and Distributors, Delhi India. pp 13: 738-739.

Amisu, K.O; Coker, A. O.; On SLW, Isokpehi, R. D. (2003). Arcobacter butzlieri strains from poultry abattoir effluent in Nigeria. East Afri. Med. J., 80: 218221.

Association of Official Analytical Chemists, (AOAC) (1984). Water and salt official method of Analysis.14th edition Virgina, USA

Bain, R.; Cronk, R.; Hossain, S.; Bonjour, K. and Onda, J. (2014). Wright, Global assessment of exposure to faecal contamination through drinking water based on systematic review, Trop. Med. Int. Health, 19: 917-927.

Bloem, E.; Albihn, A.; Elving, J.; Hermann, L.; Lehmann, L.; Sarvi, M.; Schaaf, T.; Schick, J.; Turtola, E. and Ylivainio, K. (2017). Contamination of organic nutrient sources with potentially toxic elements, antibiotics and pathogen microorganisms in relation to $\mathrm{P}$ fertilizer potential and treatment options for the production of sustainable fertilizers: a review. Sci Total Environ (607-608): 225-242.

Boyde, E.C. and Craig, S.T. (2009). Water quality and aquaculture. Pond aquaculture water quality and management. Springer India private Ltd. P1.

Boudoukha, A. and Boulaarak, M. (2013). Waters pollution of Hammam Grouz Dam by nutrients (East of Algeria). Bull Serv Geol., 24 (2): 23 - 34.

Carey, R.O. and Migliaccio, K.W. (2009). Contribution of wastewater treatment plant effluents to nutrient dynamics in aquatic systems. Environ. Manag., 44(2): 205217.

Cheesbrough, M. (2000). Bacteriological Testing of water in: District Laboratory Practices in Tropical Countries. Cambridge Low Price Edition, Cambridge University Press, Cambridge, United Kingdom, pp.434.

Choudhary, P.; Dhakad, N.K. and Jain, R. (2014). Studies on the Physico-Chemical Parameters of Bilawali Tank, Indore (M.P.) India. IOSR Journal Of Environmental Science, Toxicology And Food Technology (IOSR-JESTFT). 8 (1): $37-40$.

Delpla, I.; Jung, A. V.; Baures, E.; Clement, M. and Thomas, O. (2009). Impacts of climate change on surface water quality in relation to drinking water production. Environmental International, 35: 1225-1233.

Deutsch M, (2003). Natural controls involved in shallow Aquifer contamination. Ground Water 3.U.S Environmental Protection Agency, 37 - 58.

DWA (Department of Water Affairs) (2006). A Drinking Water Quality Framework for South Africa. Government Printer, Pretoria, South Africa. 104 pp.

Environmental Protection Agency EPA, (2014). Drinking Water Parameters Microbiological, Chemical and Indicator Parameters in the 2014 Drinking 
Water Regulations 2014. An overview of parameters and their importance. Wexford Ireland.

Guizani, M.; Fujii, T.; Hijikata, N. and Funamizu, N. (2016). Salt removal from soil during rainy season of semi-arid climate following an assumed salt accumulation from previous cultivations fertilized with urine. EuroMediterranean Journal for Environmental Integration. 1 (1).

Gulumbe, B. H.; Aliyu, B. and Manga, S. S. (2016). Bacteriological and Physicochemical Analyses of Aliero Dam Water. International Journal of Inno-vative Studies in Sciences and Engineering Technology (IJISSET). 2 (4): 30 - 43.

Kamal, D.; Khan A.N.; Rahman, M.A. and Ahamed, F. (2007). Study on the Physicochemical properties of water of Mouri River, Khulna, Bangladesh. Pakistan Journal of Biological Sciences 10(5): 710-717.

Lamikaran, A. (1999). Essential Microbiology for students and Practitioners of Pharmacy, Medicine and Microbiology. 2nd Edn. Amkra books, 406p.

Letterman, R. D. and Driscoll, C.T. (1994). Control of residual aluminum in filtered water. AWWA RF Report, AWWA, Denver, CO80235. 1 - 93.

Magnien, R.; Marshall, H. G.; Sellner, K.; Stockwell, D. A.; Stoecker, D. K., and Suddleson, M. (2008). Eutrophication and harmful algal blooms: a scientific consensus. Harmful Algae, (8): 3-13.

Majumder, S.; Gupta S.; Saha, R.N.; Datta, J.K. and Mandal, N. (2006). Eutrophication potential of Municipal sewage of Burdwan town, West Bengal, India, Pollut. Res., 25(2): 299 - 302.

Mebarkia A. (2011). Studies of physico-chemical characteristics of surface waters.Case of the dam Ain zada wilaya of Bordj Bou-Arreridj. (NortheasternAlgeria). Magister dissertation. Univ. Annaba. 209 p.

Mebarkia, A.; Haouchine, A.; Boudoukha, A. and Nedjai, R. (2017). Assessment of nutrient contamination in surface water, case study of Ain Zada Dam (North North - East of Algeria). J FundamAppl Sci. 9(3): 1358-1377.

Medeiros, R. S.; Lopez, B. A.; Sampaio, L. A.; Romano, L. A. and Rodrigues, R. V. (2016). Ammonia and nitrite toxicity to false clownfish Amphiprion ocellaris, Aquacult. Int. 24: 985-993.

Mimeche, F. and Biche, M. (2015). Length-weight relationships of four non-natives cyprinid from the semiarid region in North-East of Algeria. AACL Bioflux, 8 (1): $82-88$.

Nkamare, M.B.; Ofili A. N. and Adeleke, A. J. (2012). Physico-chemical and microbiological assessment of borehole water in Okutukutu, Bayelsa State, Nigeria. Advances in Applied Science Research, 3 (5):2549-2552.

Nebojša, P.; Aleksandra, M. D.; Danijela, B. M.; Jelenadj, B. P., and Aleksandar, Ž. K. (2017). Evaluation of the quality of drinking water in Rasina District, Serbia: physicochemical and bacteriological viewpoint. Romanian Journal of Physics (62), 818.

Nidhi Saxena, Misra, S. N. and Shukla, R. N. (2011). Physicochemical and Bacteriological Analysis of Water Quality Under Different Environmental Condition. J. Chem. Pharm. Res., 3(2):162-167

Okorafor, K. A.; Agbo, B. E.; Johnson, A. M. and Chiorlu, M. (2012). Physicochemical and bacteriological characteristics of selected streams and boreholes in Akamkpa and Calabar Municipality, Nigeria. Archives of Applied Science Research, 4 (5): 2115-2121. 
Park, J.; Duan, L.; Kim, B.; Mitchell, M. J. and Shibata, H. (2010). Potential effects of climate change and variability on watershed biogeochemical processes and water quality in Northeast Asia. Environmental International 36, 212-225.

Reichwaldt, E. S., and Ghadouani, A. (2012). Effects of rainfall patterns on toxic cyanobacterial blooms in a changing climate: between simplistic scenarios and complex dynamics. Water Research, 46(5): 1372-1393.

Roopavathi, C.; Mamatha, S. S. and N. S. Raju (2016). Assessment of physicochemical and bacteriological drinking water quality of different sources of H.D. Kote town, Mysore district. Int. Journal of Engineering Research and Application. 6, (7): 45-51.

Rout, C. and Sharma, A. (2011). Assessment of drinking water quality: A case study of Ambala cantonment area, Haryana, India. International Journal of Environmental Sciences 2 (2): 933 - 945.

Ryma, B. and Mouloud, B. (2018). The wintering behavior of common coot Fulica atra L. in the Hauts Plateaux, Northeast Algeria. International Journal of Biosciences. 12 (1): 230-241.

Sakhel, S. R.; Geissen, S.U. and Vogelpohl, A. (2017). Virtual industrial water usage and wastewater generation in the Middle East and North Africa 2011-2015. Euro-Mediterranean Journal for Environmental Integration. 2(1).

Saoudi, A.; Brient, L.; Boucetta, S.; Ouzrout R.; Bormans, M. and Bensouilah, M. (2017). Management of toxic cyanobacteria for drinking water production of Ain Zada Dam. Environ Monit Assess. 189: 361.

Singh, S. K.; Kanth, M. K.; Kumar, D.; Raj, R.; Kashyap, A.; Jha, P. K.; Anand, A.; Puja, K.; Kumari, S.; Ali, Y.; Lokesh, R. S. and Kumar, S. (2017). Physicochemical and Bacteriological Analysis of Drinking Water Samples from Urban Area of Patna District, Bihar, India. Int. J. Life. Sci. Scienti. Res.; 3(5):1355-1359.

SON, (2003). Standard organization of Nigeria safe drinking water regulation.

Taiwo, A.A.; Ijaola, T.O.; Jiboku, O.; Oluwadare, I. and Osunkiyesi, A. (2012). Physicochemical and Bacteriological Analyses of Well Water in Abeokuta Metropolis, Ogun -State, Nigeria. IOSR Journal of Applied Chemistry (IOSRJAC). 2(6): $29-35$.

Trivedi, P.R. and Raj, G. (1997). Water pollution encyclopedia of environmental sciences Akashdeep publishing house. India. (25): 139-162.

Waters-Doughty, H. (1924). Mohr's method for the determination of silver and halogens in other then neutral solutions, J. Am. Chem. Soc. (46): 2707-2709.

World Health Organization WHO (1993). Guidelines for drinking water quality-I, Recommendations. $2^{\text {nd }}$ Ed. Geneva. 1 - 4.

World Health Organization WHO (1999). Guidelines for drinking water quality. (5): $10-15$.

World Health Organization WHO (2004). Safe Piped Water: Managing Microbial Water Quality in Piped Distribution Systems. Edited by Richard Ainsworth. ISBN: 184339039 6. Published by IWA Publishing, London, UK.

World Health Organization WHO (2009). Calcium and Magnesium in Drinkingwater: Public health significance, Geneva, Cotruvo J, Bartram J, Eds.

World Health Organization WHO (2011). Guidelines for Drinking Water Quality, Genève: WHO. Press, $4^{\text {th }}$ Ed.

Zangen, M. (1962). Titration of carbonate-bicarbonate leach solutions. Journal of Chemical Technology and Biotechnology., 12(2): 92-96. 